\title{
PENGARUH KREDIT MACET TERHADAP PROFITABILITAS PT BANK RAKYAT INDONESIA, TBK PERIODE 2016-2019
}

\author{
Kemas Welly Angga Permana \\ Email: kemaswelly@unisti.ac.id \\ Universitas Sjakhyakirti Palembang
}

\begin{abstract}
ABSTRAK
Penelitian ini adalah untuk mengetahui pengaruh Kredit Macet terhadap Profitabilitas pada PT. Bank Rakyat Indonesia (Persero) Tbk periode 2016-2019. Rasio yang digunakan dalam perhitungan rasio profitabilitas adalah Return On Assets (ROA) dan Return On Equity (ROE).

Penelitian ini termasuk jenis penelitian eksperimen, dimana suatu penelitian yang berusaha mencari pengaruh variabel tertentu terhadap variabel yang lain dalam kondisi yang terkontrol secara ketat. Sampel dalam penelitian ini adalah rasio profitabilitas dan NPL pada tahun 2016-2019. Data yang diperoleh dalam penelitian ini di ambil melalui situs resmi dari BEI (www.idx.co.id). Sedangkan teknik analisis data menggunakan telnik analisis kuantitatif dan teknik analisis regresi linear sederhana melalui program SPSS for windows versi 23.

Hasil penelitian menunjukan bahwa kredit macet berpengaruh secara signifikan terhadap profitabilitas.

Kata Kunci: Kredit Macet, Rasio Profitabilitas, NPL
\end{abstract}

\section{PENDAHULUAN}

\section{LATAR BELAKANG}

Sebagai lembaga keuangan, peranan bank dalam perekonomian sangatkan dominan. Hampir semua kegiatan perekonomian masyarakat membutuhkan bank dengan fasilitas kreditnya. Oleh karena itu, bank merupakan lembaga keuangan yang fungsi utamanya adalah menarik dana dari masyarakat dan menghimpunnya dalam bentuk simpanan, maka bank kemudian menyalurkan dana tersebut dalam bentuk kredit atau pinjaman kepada masyarakat guna meningkatkan perkembangan ekonomi usahanya.

Menurut Undang-Undang No. 7 tahun 1992 tentang perbankan, sebagaimana telah diubah dengan Undang-Undang No. 10 tahun 1998, disebutkan kredit adalah penyediaan uang atau tagihan yang dapat dipersamakan dengan itu, 
berdasarkan persetujuan atau kesepakatan pinjam-meminjam antara bank dan pihak lain yang mewajibkan pihak peminjam untuk melunasi hutangnya setelah jangka waktu tertentu dengan pemberian bunga.

Tabel dibawah ini merupakan jumlah NPL pada PT. Bank Rakyat Indonesia (Persero) Tbk. Periode Tahun 2016-2019 sebagai berikut :

\section{Tabel 1}

\section{Jumlah NPL}

\begin{tabular}{|c|c|}
\hline Tahun & NPL (\%) \\
\hline $\mathbf{2 0 1 6}$ & 1,36 \\
\hline $\mathbf{2 0 1 7}$ & 1,31 \\
\hline $\mathbf{2 0 1 8}$ & 1,78 \\
\hline $\mathbf{2 0 1 9}$ & 4,86 \\
\hline
\end{tabular}

Sumber:PT.Bank Rakyat Indonesia (Persero) Tbk, 2019

Berdasarkan tabel 1 di atas maka dapat kita ketahui bahwa jumlah NPL mengalami penurunan pada tahun 2017 sebesar 0,5\%.

Melalui kegiatan perkreditan dan berbagai jasa yang diberikan, bank melayani kegiatan pembiayaan serta melancarkan mekanisme sistem pembayaran bagi semua sektor perekonomian. Besarnya jumlah kredit yang disalurkan akan menetukan keuntungan bank. Jika bank tidak mampu menyalurkan kredit, sementara dana yang terhimpun dari simpanan banyak, akan menyebabkan bank tersebut rugi. Akan tetapi, dengan adanya pemberian kredit kepada masyarakat, pihak bank juga harus mempertimbangakan resiko-resiko kredit yang timbul dari adanya kredit bermasalah, karena kredit macet tidak saja akan merugikan para pemilik pemegang saham bank tersebut, tetapi juga akan merugikan para pemilik dana yang sebagian besar adalah anggota masyarakat dari berbagai lapisan dan tingkat kehidupan yang meresakan masyarakat bahkan merusak perekonomian suatu negara.

\section{Perumusan Masalah}

Berdasarkan latar belakang dirumuskan permasalahan:“ Bagaimanakah Pengaruh Kredit Macet Terhadap Profitabilitas pada PT. Bank Rakyat Indonesia (Persero?“ 


\section{KAJIAN PUSTAKA}

\section{Kredit}

Menurut Kasmir (2011), dalam arti luar kredit diartikan sebagai kepercayaan. Kata kredit berasal dari bahasa Latin yaitu "credere" yang berarti percaya. Maksud percaya bagi pemberi kredit ialah percaya kepada penerima kredit behwa kredit yang disalurkan pasti akan dikembalikan sesuai perjanjian, sedangkan bagi penerima kredit merupakan pemberian kepercayaan sehingga penerima kredit memiliki kewajiban untuk membayar sesuai dengan jangka waktu yang disepakati bersama.

\section{Kredit Macet}

Menurut Usman (2001: 255-260), "Untuk menetukan apakah suatu kredit dikatakan bermasalah atau macet didasarkan pada kolektibilitas kreditnya".

Kredit macet sering disebut dengan Non Performing Loan (NPL) yaitu alat ukur yang digunakan untuk mengatur resiko kredit. Pemberian kredit yang dilakukan oleh bank mengandung risiko yaitu berupa tidak lancarnya pembayaran kredit. Non Performing Loan (NPL) mencerminkan risiko kredit, semakin tinggi tingkat NPL maka semikin besar pulsa resiko kredit yang ditanggung oleh pihak bank. Akibat tingginya NPL perbankan harus menyediakan pencadangan yang lebih besar sehingga pada akhirnya modal bank ikut terkikis.

Bank Indonesia menetapkan bahwa tingkat Non Performing Loan (NPL) yang wajar sebesar 5\% dari total kreditnya. Hal ini dapat disimpulkan bahwa bank dapat dikategorikan sehat apabila Non Performing Loan (NPL) dibawah 5\%, apabila rasio NPL berada diatas 5\% dapat dikatakn bank tersebut tidak sehat. Untuk mengetahui besarnya tingkat Non Performing Loan (NPL) suatu bank maka diperlukan suatu ukuran.

\section{Faktor Faktor Penyebab Kredit Macet}

Faktor-faktor penyebah kredit macet menurut Mudrajad Kuncoro dan Suhardjono (2002:472) yaitu sebagai berikut :

a. Faktor Eksternal Bank

1) Adanya maksud tidak baik dari para debitur yang diragukan.

2) Adanya kesulitan atau kegagalan dalam proses likuiditas dari perjanjian kredit yang telah disepakati anatara debitur dengan bank. 
3) Kondisi manajeman dan lingkungan usaha debitur.

4) Musibah (misalnya: kebakaran, bencana alam) atau kegagalan usaha.

a. Faktor Internal Bank

1) Kurang adanya pengetahuan dan keterampilan para pengelola kredit.

2) Tidak adanya kebijakan perkreditan pada bank yang bersangkutan.

3) Pemberian dan pengawasan kredit yang dilakukan oleh bank menyimpang dari prosedur yang telah ditetapkan.

4) Lemahnya organisasi dan manajemen dari bank yang bersangkutan.

\section{Profitabilitas}

Menurut Dendawijaya (2000:119-122), profitabilitas dapat diukur menggunakan tiga rasio, yaitu Rasio Return On Assets, Return On Equity, dan Net Profit Margin.

1. Rasio Return On Assets

Rumusnya :

Return On Assets $=\frac{\text { Laba Bersih Sebelum Pajak }}{\text { Total Aktiva }} \times 100 \%$

Rasio ini digunakan untuk mengukur kemampuan manjemen bank dalam memperoleh keuntungan (laba) secara keseluruhan. Semakin besar ROA suatu bank, semakin besar pula tingkat keuntungan yang dicapai bank tersebut dan semakin baik pula posisi bank tersebut dari segi penggunaan aset.

2. Rasio Return On Equity

Rumusnya :

$$
\text { Return On Equity }=\frac{\text { Laba Bersih Setelah Pajak }}{\text { Modal Sendiri }} \times 100 \%
$$

ROE menunjukan kemampuan manajemen bank dalam mengelola modal yang tersedia untuk menunjukan net income. Semakin tinggi return semakin baik karena deviden yang dibagikan akan bertambah kembali sebagai retained earning juga semakin baik.

3. Rasio Net Profit Margin

Rumusnya :

$$
\text { Net Profit Margin }=\frac{\text { Laba Bersih }}{\text { Pendapatan Operasional }} \times 100 \%
$$


NPM adalah rasio yang menggambarkan tingkat keuntungan (laba) yang diperoleh bank dibandingkan dengan pendapatan yang diterima dari kegiatan operasionalnya.

\section{METODOLOGI PENELITIAN}

\section{Desain Penelitian}

Desain penelitian yang dilakukan dalam penelitian ini adalah dengan pendekatan deskriptif, yang mana menurut menurut Moh. Nazir (2005:84) dalam bukunya Metode Penelitian menerangkan bahwa: "Desain penelitian adalah semua proses yang diperlukan dalam perencanaan dan pelaksanaan penelitian”.

\section{Lokasi Penelitian}

Lokasi penelitian dilakukan melalui Bursa Efek Indonesia (BEI) Pusat yang bisa diakses melalui internet situs resmi BEI yaitu https://www.idx.co.id/ di. PT. Bank Rakyat Indonesia (Persero).

\section{Metode Pengumpulan dan Analisa Data}

Teknik pengambilan data dalam penelitian ini adalah data primer, yaitu dengan cara mengadakan teknik survey, observasi dan dengan dokumentasi. Sedangkan data diolah dengan analisis nonstatistik yang berupa analisa kelayakan investasi usaha rumah burung walet ditinjau dari aspek finansial melalui data-data investasi, biaya dan pendapatan. Analisis kriteria investasi tersebut meliputi: (1) NPL

Bank Indonesia menetapkan bahwa tingkat Non Performing Loan (NPL) yang wajar sebesar 5\% dari total kreditnya. Hal ini dapat disimpulkan bahwa bank dapat dikategorikan sehat apabila Non Performing Loan (NPL) dibawah 5\%, apabila rasio NPL berada diatas 5\% dapat dikatakan bank tersebut tidak sehat.

(2) Analisis Regresi Sederhana (Simple Regression)

a) Regresi Linear Sederhana

Menurut Sugiyono (2015:188), analisi regresi sederhana digunakan untuk mengetahui pengaruh antara dua variabel yang diteliti. Maka regresi linear sederhana (simple regression) dipakai untuk melakukan prediksi seberapa besar nilai variabel dependen jika nilai variabel independen dirubah, dengan persamaan: 


$$
\mathbf{Y}=\boldsymbol{\alpha}+\mathbf{b X}+\mathbf{e}
$$

Dimana :

Y : Profitabilitas

$\alpha$ : Konstanta atau bila harga $\mathrm{X}=0$

b : Koefisien Regresi

X : Kredit Macet

e : error item

b) Koefisien Korelasi (r)

Untuk mengetahui keeratan pengaruh antara variabel independen (X) terhadap variabel dependen (Y). Nilai koefisen korelasi paling kecil -1 dan paling besar 1, jadi kalau nilai $\mathrm{r}$ dapat dinyatakan $-1<\mathrm{r}>1$ artinya apabila $\mathrm{r}=$ 1 atau -1 maka ada pengaruh, sedangkan $r=0$ artinya tidak ada pengaruh.

\section{c) Koefisien Determinasi $\left(\mathbf{R}^{2}\right)$}

Koefisien determinasi $\left(\mathrm{R}^{2}\right)$ sering pula disebut dengan koefisien determinasi majemuk (multiple coefficient of determination) yang hampir sama dengan $\mathrm{r}^{2} . \mathrm{R}^{2}$ menjelaskan proporsi variasi dalah variabel terikat (Y) yang dijelaskan oleh varibel bebas dan cenderung meningkat nilainya sejalan dengan peningkatan jumlah variabel bebas, menghitung koefisien determinasi dengan cara mengkuadratkan koefisien korelasi $\left(\mathrm{r}^{2}\right)$ kali $100 \%$ yaitu :

$$
R=\mathbf{r}^{2} \times 100 \%
$$

Keterangan :

$\mathrm{R}=$ Koefisien Determinasi

$\mathrm{r}=$ Koefisien Korelasi

(3) Rancangan Uji Hipotesis

Rancangan pengujian hipotesis ini dimulai dengan penetapan hipotesis no $\left(\mathrm{H}_{0}\right)$ dan hipotesis alternatif $\left(\mathrm{H}_{\mathrm{a}}\right)$. Hipotesis yang dikemukakan dalam penelitian ini adalah Pengaruh Kredit Macet terhadap Profitabilitas pada PT. Bank Rakyat Indonesia Tahun 2016-2019.

Dari penjelasan diatas dapat ditarik kesimpulan, yaitu :

$\mathrm{H}_{0}=$ Kredit Macet berpengaruh secara signifikan terhadap Profitabilitas .

$\mathrm{H}_{\mathrm{a}}=$ Kredit Macet tidak berpengaruh secara signifikan terhadap Profitabilitas . 
Untuk menentukan apakah hipotesis $\mathrm{H}_{0}$ ditolak atau diterima dengan cara membandingkan $r_{\text {hitung }}$ dengan $r_{\text {tabel }}$ dengan ketetntuan sebagai berikut :

Apabila $\mathrm{r}_{\text {hitung }}<\mathrm{r}_{\text {tabel }}$, maka $\mathrm{H}_{\mathrm{o}}$ diterima $\mathrm{H}_{\mathrm{a}}$ ditolak

Apabila $r_{\text {hitung }} \geq r_{\text {tabel }}$, maka $\mathrm{H}_{\mathrm{a}}$ diterima $\mathrm{H}_{0}$ ditolak

Dari perhitungan korelasi tersebut dapat diketahui hubungan antara variabel bebas (X) yaitu Kredit Macet dan variabel terikat (Y) yaitu Profitabilitas dengan menggunakan kriteria menurut Sugiyono (2015:184).

\section{a. Uji Secara Simultan (Uji F)}

Pengujian ini dilakukan untuk mengetahui secara bersama-sama apakah variabel bebas berpengaruh signifikan atau tidak terhadap variabel terkait (Ghozali, 2005). Uji F dilakukan untuk melihat pengaruh variabel bebas secara bersama-sama terhadap variabel tidak bebas.

Hipotesisnya :

1. Bila Fhitung < Ftabel, variabel bebas secara bersama-sama tidak berpengaruh terhadap variabel dependen

2. Bila Fhitung > Ftabel, variabel bebas secara bersama-sama berpengaruh terhadap variabel dependen.

\section{b. Uji Parsial (Uji-t)}

Uji parsial menggunakan uji t untuk menguji seberapa jauh pengaruh satu variabel penjelasan atau independen secara individual dalam menerangkan variasi variabel dependen (Imam Ghozali 2011:98)

Pengaruh Kredit Macet (X) terhadap Profitabilitas (Y).

Hipotesisnya :

$\mathrm{H}_{0}: \mathrm{b}=\mathrm{O} \longrightarrow$ tidak ada pengaruh Kredit Macet $(\mathrm{X})$ terhadap Profitabilitas (Y).

$\mathrm{H}_{\mathrm{a}}: \mathrm{b} \neq 0 \longrightarrow$ ada pengaruh Kredit Macet terhadap Profitabilitas (Y).

Berdasarkan analisis regresi menggunakan uji t, maka akan diambil keputusan dengan kinerja pengambilan keputusan sebagai berikut :

a. $\mathrm{H}_{0}$ ditolak jika t sig $>0,05$

b. $\mathrm{H}_{\mathrm{a}}$ diterima jika $\mathrm{t} \operatorname{sig} \leq 0,05$. 
Jurnal Ilmiah Akuntansi Rahmaniyah (JIAR)

Vol. 3 No.2, Juni 2020, 66-85

Permana

\section{HASIL DAN PEMBAHASAN}

\section{Hasil Penelitian}

Pada penelitian ini teknik analisis data yang digunakan adalah regresi linear sederhana. Teknik analisis ini digunakan untuk mengetahui besarnya pengaruh kredit macet terhadap profitabilitas bank (Return On Assets dan Return On Equity). Hasil analisis regresi linear sederhana yang telah dilakukan dengan menggunakan bantuan program Statistical Product and Service Solution (SPSS versi 23) adalah sebagai berikut :

a. Analisis Regresi Linear Sederhana ROA

Tabel 2

Hasil Analisis Regresi Linear Sederhana ROA

Coefficients $^{\mathrm{a}}$

\begin{tabular}{|c|c|c|c|c|c|}
\hline \multirow[b]{2}{*}{ Model } & \multicolumn{2}{|c|}{ Unstandardized Coefficients } & \multirow{2}{*}{$\begin{array}{c}\text { Standardized } \\
\text { Coefficients }\end{array}$} & \multirow[b]{2}{*}{$\mathrm{T}$} & \multirow[b]{2}{*}{ Sig. } \\
\hline & $\mathrm{B}$ & Std. Error & & & \\
\hline (Constant) & 1,608 & 039 & & 41,581 &, 001 \\
\hline KREDIT MACET & ,278 & 014 & ,997 & 19,829 & ,003 \\
\hline
\end{tabular}

a. Dependent Variable: ROA

Sumber : Output SPSS 23, 2020

Model persamaan regresi linear sederhana Return On Assets (ROA) adalah sebagai berikut :

$Y=\alpha+b X+e$

Dengan demikian berdasarkan hasil tabel 4.5 adalah :

$\mathrm{Y}=$ Return On Assets (ROA)

$\alpha($ constanta $)=1,608$

$\mathrm{bX}($ Kredit Macet $)=0,278$

$\mathrm{e}=$ eror item

Sehingga diperoleh :

$\mathrm{Y}=1,608+0,278 \mathrm{X}$

Dari persamaan di atas dapat dijelaskan bahwa :

a. Nilai konstanta sebesar 1,608 mengidentifikasikan bahwa jika variabel independen (Kredit Macet) adalah nol maka Return On Assets bernilai 1,608 . 
b. Nilai koefisien regresi variabel kredit macet bernilai positif yaitu 0,278 yang dapat diartikan apabila setiap terjadinya kenaikan kredit macet sebesar Rp. 1,- maka Return On Assets akan mengalami kenaikan sebesar 0,278 .

Dari hasil persamaan tersebut dapat diperoleh penjelasan bahwa variabel kredit macet mempunyai pengaruh yang positif terhadap Return On Assets (ROA).

b. Analisis Regresi Linear Sederhana ROE

Tabel 3

Hasil Analisis Regresi Linear Sederhana ROE

Coefficients $^{\mathbf{a}}$

\begin{tabular}{|c|c|c|c|c|c|c|}
\hline \multirow{2}{*}{\multicolumn{2}{|c|}{ Model }} & \multicolumn{2}{|c|}{ Unstandardized Coefficients } & $\begin{array}{l}\text { Standardized } \\
\text { Coefficients }\end{array}$ & \multirow[b]{2}{*}{$\mathrm{t}$} & \multirow[b]{2}{*}{ Sig. } \\
\hline & & $\mathrm{B}$ & Std. Error & Beta & & \\
\hline \multirow[t]{2}{*}{1} & (Constant) & 6,502 & 104 & & 62,276 & ,000 \\
\hline & KREDIT MACET & ,792 & 040 & ,997 & 19,650 & 003 \\
\hline
\end{tabular}

a. Dependent Variable: ROE

Sumber : Output SPSS, 2020

Model persamaan regresi linear sederhana Return On Equity (ROE) adalah sebagai berikut :

$Y=\alpha+b X+e$

Dengan demikian berdasarkan hasil tabel 4.6 adalah :

$\mathrm{Y}=$ Return On Equity (ROE)

$\alpha($ constanta $)=6,502$

$\mathrm{bX}($ Kredit Macet $)=0,792$

$\mathrm{e}=$ eror item

Sehingga diperoleh :

$\mathrm{Y}=6,502+0,792 \mathrm{X}$

Dari persamaan di atas dapat dijelaskan bahwa :

a. Nilai konstanta sebesar 6,502 mengidentifikasikan bahwa jika variabel independen (Kredit Macet) adalah nol maka Return On Equity bernilai 6,502 .

b. Nilai koefisien regresi variabel kredit macet bernilai positif yaitu 0,792 yang dapat diartikan apabila setiap terjadinya kenaikan kredit macet 
sebesar Rp. 1,- maka Return On Equity akan mengalami kenaikan sebesar 0,792 .

Dari hasil persamaan tersebut dapat diperoleh penjelasan bahwa variabel kredit macet mempunyai pengaruh yang positif terhadap Return On Equity (ROE).

\subsubsection{Koefisien Korelasi ( $r)$}

Koefisien korelasi (r) ini digunakan untuk mengetahui keeratan pengaruh antara variabel independen (X) dengan hubungan variabel dependen (Y).

Nilai koefisien berkisar antara -1 dan 1 . Semakin mendekati satu nilai absolut koefisien korelasi maka hubungannya dengan variabel tersebut semakin kuat, sedangkan semakin kecil atau mendekali nol nilai absolut koefisien korelasi maka hubungan antar variabel tersebut semakin lemah, tanda positif dan negatif menunjukan arah hubungan.

\section{a. Koefisien Korelasi (r) ROA}

\section{Tabel 4}

Hasil Uji Koefisien Korelasi ROA

\section{Correlations}

\begin{tabular}{|ll|r|r|}
\hline & & KREDIT & \multicolumn{1}{c|}{ ROA } \\
\hline KREDIT MACET & Pearson Correlation & 1 &, $997^{* *}$ \\
& Sig. (2-tailed) & &, 003 \\
& $\mathrm{~N}$ & 4 & 4 \\
\hline ROA & Pearson Correlation &, $997^{* *}$ & 1 \\
& Sig. (2-tailed) &, 003 & \\
& $\mathrm{~N}$ & 4 & 4 \\
\hline
\end{tabular}

**. Correlation is significant at the 0.01 level (2-tailed). Sumber : Output SPSS, 2020

Berdasarkan Tabel 4 di atas menunjukkan bahwa nilai korelasinya yaitu 0,997. Dengan begitu dapat dinyatakan ada hubungan antara Variabel Kredit Macet (X) dengan Variabel Return On Assets (ROA) (Y) yang dikategorikan "Sangat Kuat"

\section{b. Koefisien Korelasi (r) ROE}

Tabel 5

Hasil Uji Koefisien Korelasi ROE

Correlations 


\begin{tabular}{|ll|r|r|}
\hline & & KREDIT & \\
& MACET & \multicolumn{1}{c|}{ ROE } \\
\hline KREDIT MACET & Pearson Correlation & 1 &, $997^{* *}$ \\
& Sig. (2-tailed) & &, 003 \\
& $\mathrm{~N}$ & 4 & 4 \\
\hline ROE & Pearson Correlation &, $997^{* *}$ & 1 \\
& Sig. (2-tailed) &, 003 & \\
& $\mathrm{~N}$ & 4 & 4 \\
\hline
\end{tabular}

**. Correlation is significant at the 0.01 level (2-tailed).

Sumber : Output SPSS, 2020

Berdasarkan Tabel 5 di atas menunjukkan bahwa nilai korelasinya yaitu 0,997 . Dengan begitu dapat dinyatakan ada hubungan antara Variabel Kredit Macet (X) dengan Variabel Return On Equity (ROE) (Y) yang dikategorikan "Sangat Kuat".

\subsubsection{Koefisien Determinasi $\left(R^{2}\right)$}

Untuk menentukan koefisien determinasi yang gunanya untuk mengukur seberapa besar pengaruh nilai suatu variabel independen dapat dijelaskan terhadap perubahan variabel dependen. Tabel dibawah ini hasil perhitungan nilai koefisien determinasi dari Return On Assets (ROA) dan Return On Equity (ROE) sebagai berikut :

a. Koefisien Determinasi $\left(\mathbf{R}^{2}\right)$ ROA

Tabel 6

Hasil Koefisien Determinasi $\left(\mathbf{R}^{2}\right)$ ROA

Model Summary

\begin{tabular}{|l|r|r|r|r|}
\hline Model & R & R Square & Adjusted R Square & \multicolumn{2}{|c|}{$\begin{array}{c}\text { Std. Error of the } \\
\text { Estimate }\end{array}$} \\
\hline 1 &, $997^{\mathrm{a}}$ &, 995 &, 992 &, 04137 \\
\hline
\end{tabular}

a. Predictors: (Constant), Kredit Macet

Sumber : Output SPSS, 2020

Dari hasil perhitungan dengan menggunakan program SPSS versi 23 pada tabel 6 dapat diketahui bahwa nilai koefisien determinasi $\left(\mathrm{R}^{2}\right)$ sebesar 99,5\% yang berarti bahwa variabel kredit macet dalam penelitian ini mempengaruhi variabel Return On Assets (ROA) sebesar 99,5\% sedangkan sebesar $0,5 \%$ dipengaruhi oleh variabel lain yang tidak diteliti. 
b. Analisis Koefisien Determinasi $\left(\mathbf{R}^{2}\right) \mathrm{ROE}$

Tabel 7

Hasil Koefisien Determinasi $\left(\mathbf{R}^{2}\right)$ ROE

Model Summary

\begin{tabular}{|l|r|r|r|r|}
\hline Model & & & & \multicolumn{2}{c|}{$\begin{array}{c}\text { Std. Error of the } \\
\text { Estimate }\end{array}$} \\
\hline 1 & $\mathrm{R}$ & \multicolumn{1}{|c|}{ R Square } & Adjusted R Square &, 992 \\
\hline
\end{tabular}

a. Predictors: (Constant), Kredit Macet

Sumber : Output SPSS, 2020

Dari hasil perhitungan dengan menggunakan program SPSS versi 23 pada tabel 7 dapat diketahui bahwa nilai koefisien determinasi $\left(\mathrm{R}^{2}\right)$ sebesar 99,5\% yang berarti bahwa variabel kredit macet dalam penelitian ini mempengaruhi variabel Return On Equity (ROE) sebesar 99,5\% sedangkan sebesar $0,5 \%$ dipengaruhi oleh variabel lain yang tidak diteliti.

\subsubsection{Uji F (Secara Simultan)}

Uji F digunakan untuk mengetahui apakah variabel independen berpengaruh signifikan terhadap variabel dependen. Hasil uji pengaruh variabel kredit macet terhadap profitabilitas (ROA dan ROE).

\section{a. Return On Assets (ROA)}

\section{Tabel 8}

Hasil Uji F Return On Assets (ROA) ANOVA $^{\mathrm{a}}$

\begin{tabular}{|ll|r|r|r|r|r|}
\hline Model & & Sum of Squares & Df & Mean Square & F & Sig. \\
\hline 1 & Regression &, 673 & 1 &, 673 & 393,175 &, $003^{\mathrm{b}}$ \\
& Residual &, 003 & 2 &, 002 & & \\
& Total &, 676 & 3 & & & \\
\end{tabular}

a. Dependent Variable: ROA

b. Predictors: (Constant), KREDIT MACET

Sumber: Output SPSS, 2020

Tahap- tahap untuk melakukan uji $\mathrm{F}$ adalah sebagai berikut :

a. Merumuskan Hipotesis

$\mathrm{H}_{01}=$ Kredit Macet tidak berpengaruh terhadap Return On Asset (ROA)

$\mathrm{H}_{\mathrm{a} 1}=$ Kredit Macet berpengaruh terhadap Return On Asset (ROA)

b. Menentukan tingkat signifikansi 
Tingkat signifikan menggunakan $\mathrm{a}=5 \%$ atau $0,05 \%$. Signifikan $5 \%$ atau $0,05 \%$ adalah ukuran standar yang sering digunakan dalam penelitian.

c. Menetukan F hitung

Dari hasil perhitungan SPSS diperoleh nilai $F_{\text {hitung }}$ sebesar 393,175.

d. Menentukan F tabel

$\mathrm{a}=5 \%, \mathrm{df} 1=\mathrm{k}-1=2-1=1, \mathrm{df} 2=\mathrm{n}-\mathrm{k}=4-2=2$. Dimana $\mathrm{n}$ adalah jumlah sampel dan $\mathrm{k}$ adalah jumlah variabel), hasil diperoleh untuk $\mathrm{F}_{\text {tabel }}$ sebesar 18,51 .

e. Menentukan nilai signifikansi

Dari hasil perhitungan SPSS diperoleh nilai Sig sebesar 0,003.

f. Kriteria pengujian

Dalam penelitian ini menggunakan dua kriteria pengujian, yaitu :

$\mathrm{H}_{01}=$ diterima apabila $\mathrm{F}_{\text {hitung }}<\mathrm{F}_{\text {tabel }}$

$\mathrm{H}_{01}=$ ditolak apabila $\mathrm{F}_{\text {hitung }}>\mathrm{F}_{\text {tabel }}$

$\mathrm{H}_{01}=$ diterima apabila nilai signifikansi $>0,05$

$\mathrm{H}_{01}=$ ditolak apabila nilai signifikan $<0,05$

Berdasarkan tabel 8 diperoleh $F_{\text {hitung }}$ sebesar 393,175 dengan nilai Sig sebesar 0,003. Hal ini menunjukkan bahwa nilai $F_{\text {hitung }}$ lebih besar dari $\mathrm{F}_{\text {tabel }} 18,51$ dan nilai Sig lebih kecil dari 0,05. Maka demikian $\mathrm{H}_{01}$ ditolak dan $\mathrm{H}_{\mathrm{a} 1}$ diterima.

\section{b. Return On Equty (ROE)}

Tabel 9

Hasil Uji F Return On Equity (ROE) ANOVA ${ }^{\mathrm{a}}$

\begin{tabular}{|c|c|c|c|c|c|c|}
\hline \multicolumn{2}{|c|}{ Model } & $\begin{array}{c}\text { Sum of } \\
\text { Squares }\end{array}$ & df & Mean Square & $\mathrm{F}$ & Sig. \\
\hline \multirow[t]{3}{*}{1} & Regression & 4,314 & 1 & 4,314 & 386,112 &, $003^{b}$ \\
\hline & Residual & ,022 & 2 & ,011 & & \\
\hline & Total & 4,336 & 3 & & & \\
\hline
\end{tabular}

a. Dependent Variable: ROE

b. Predictors: (Constant), KREDIT MACET

Sumber : Output SPSS, 2020 
Tahap- tahap untuk melakukan uji F adalah sebagai berikut :

a. Merumuskan Hipotesis

$\mathrm{H}_{02}=$ Kredit Macet tidak berpengaruh terhadap Return On Equity (ROE)

$\mathrm{H}_{\mathrm{a} 2}=$ Kredit Macet berpengaruh terhadap Return On Equity (ROE)

b. Menentukan tingkat signifikansi

Tingkat signifikan menggunakan $\mathrm{a}=5 \%$ atau $0,05 \%$. Signifikan 5\% atau $0,05 \%$ adalah ukuran standar yang sering digunakan dalam penelitian.

c. Menetukan F hitung

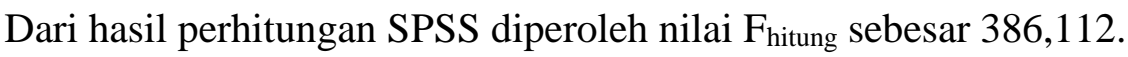

d. Menentukan F tabel

$\mathrm{a}=5 \%$, df $1=\mathrm{k}-1=2-1=1$, df $2=\mathrm{n}-\mathrm{k}=4-2=2$. Dimana $\mathrm{n}$ adalah jumlah sampel dan $\mathrm{k}$ adalah jumlah variabel), hasil diperoleh untuk $F_{\text {tabel }}$ sebesar 18,51.

e. Menentukan nilai signifikansi

Dari hasil perhitungan SPSS diperoleh nilai Sig sebesar 0,003.

f. Kriteria pengujian

Dalam penelitian ini menggunakan dua kriteria pengujian, yaitu :

$\mathrm{H}_{02}=$ diterima apabila $\mathrm{F}_{\text {hitung }}<\mathrm{F}_{\text {tabel }}$

$\mathrm{H}_{02}=$ ditolak apabila $\mathrm{F}_{\text {hitung }}>\mathrm{F}_{\text {tabel }}$

$\mathrm{H}_{02}=$ diterima apabila nilai signifikansi $>0,05$

$\mathrm{H}_{02}=$ ditolak apabila nilai signifikan $<0,05$

Berdasarkan tabel 9 diperoleh $F_{\text {hitung }}$ sebesar 386,112 dengan nilai Sig sebesar 0,003. Hal ini menunjukkan bahwa nilai $F_{\text {hitung lebih besar }}$ dari $F_{\text {tabel }} 18,51$ dan nilai Sig lebih kecil dari 0,05. Maka demikian $\mathrm{H}_{02}$ ditolak dan $\mathrm{H}_{\mathrm{a} 2}$ diterima.

\subsubsection{Uji T (Secara Parsial)}

Uji T digunaakan untuk mengetahui apakah Kredit Macet berpengaruh terhadap Profitabilitas (Return On Assets (ROA) dan Return On Equity (ROE)) dapat dilihat pada tabel dibawah ini. 
a. Hasil Uji T Return On Assets (ROA)

Tabel 10

Hasil Uji T Retrun On Assets (ROA)

Coefficients $^{\mathrm{a}}$

\begin{tabular}{|c|c|c|c|c|c|c|}
\hline \multirow{2}{*}{\multicolumn{2}{|c|}{ Model }} & \multicolumn{2}{|c|}{ Unstandardized Coefficients } & $\begin{array}{l}\text { Standardized } \\
\text { Coefficients }\end{array}$ & \multirow[b]{2}{*}{$\mathrm{t}$} & \multirow[b]{2}{*}{ Sig. } \\
\hline & & B & Std. Error & Beta & & \\
\hline & (Constant) & 1,608 & ,039 & & 41,581 & ,001 \\
\hline & KREDIT & & 010 & 007 & 1007 & 002 \\
\hline & MACET & & & & & \\
\hline
\end{tabular}

a. Dependent Variable: ROA

Sumber : Output SPSS, 2020

Tahap- tahap untuk melakukan uji $\mathrm{F}$ adalah sebagai berikut :

a. Merumuskan Hipotesis

$\mathrm{H}_{0}: \mathrm{b}=\mathrm{O} \longrightarrow$ tidak ada pengaruh Kredit Macet terhadap Return On

Assets (ROA)

$\mathrm{H}_{\mathrm{a}}: \mathrm{b} \neq 0 \longrightarrow$ ada pengaruh Kredit Macet terhadap Return On

Assets

b. Menentukan tingkat signifikan $(\alpha)=5 \%$

c. Menetukan thitung

Berdasarkan hasil uji $\mathrm{t}$ untuk variabel $\mathrm{X}$ (kredit macet) diperoleh $\mathrm{t}_{\text {hitung }}=$ 19,829 .

d. Menetukan tabel

Dengan menggunakan tingkat signifikan $(\alpha)$ sebesar 5\% untuk uji t dua arah, sehingga $\alpha / 2=0,025$ dan $\mathrm{df}=4-2=2$. Dengan demikian $\mathrm{df}=2$ maka $t_{\text {tabel }}$ adalah sebesar 4,303.

e. Menentukan kriteria pengujian

$\mathrm{r}_{\text {hitung }}<\mathrm{r}_{\text {tabel, }}$ maka $\mathrm{H}_{01}$ diterima dan $\mathrm{H}_{\mathrm{a} 1}$ ditolak

$\mathrm{r}_{\text {hitung }}>\mathrm{r}_{\text {tabel, }}$ maka $\mathrm{H}_{01}$ diterima dan $\mathrm{H}_{\mathrm{a} 1}$ ditolak

$\mathrm{H}_{01}$ diteima jika tingkat signifikan $>0,05$ maka $\mathrm{H}_{\mathrm{a} 1}$ ditolak

$\mathrm{H}_{01}$ ditolak jika tingkat signifikan $<0,05$ maka $\mathrm{H}_{\mathrm{a} 1}$ diterima

f. Keputusan Uji

$\mathrm{H}_{01}$ ditolak karena $t_{\text {hitung }}(19,829)>\mathrm{t}_{\text {tabel }}(4,303)$, maka $\mathrm{H}_{\mathrm{a} 1}$ diterima. 
$\mathrm{H}_{01}$ ditolak karena tingkat signifikan $\left.(0,003)<0.05\right)$, maka $\mathrm{H}_{\mathrm{a} 1}$ diterima.

Melalui hasil perhitungan dapat disimpulkan bahwa secara parsial Kredit Macet berpengaruh secara signifikan terhadap Return On Assets (ROA).

b. Hasil Uji T Return On Equity (ROE)

Tabel 11

Hasil Uji T Return On Equity (ROE) Coefficients $^{\mathrm{a}}$

\begin{tabular}{|c|c|c|c|c|c|c|}
\hline \multirow{2}{*}{\multicolumn{2}{|c|}{ Model }} & \multicolumn{2}{|c|}{ Unstandardized Coefficients } & \multirow{2}{*}{$\begin{array}{c}\begin{array}{c}\text { Standardized } \\
\text { Coefficients }\end{array} \\
\text { Beta }\end{array}$} & \multirow[b]{2}{*}{$\mathrm{T}$} & \multirow[b]{2}{*}{ Sig. } \\
\hline & & B & Std. Error & & & \\
\hline \multirow[t]{2}{*}{1} & (Constant) & 6,502 & ,104 & & 62,276 & ,000 \\
\hline & KREDIT MACET & & & ,997 & 19,650 & ,003 \\
\hline
\end{tabular}

a. Dependent Variable: ROE

Sumber : Output SPSS, 2020

Tahap- tahap untuk melakukan uji $\mathrm{F}$ adalah sebagai berikut :

a. Merumuskan Hipotesis

$\mathrm{H}_{0}: \mathrm{b}=0 \longrightarrow$ tidak ada pengaruh Kredit Macet terhadap Return On Equity (ROE)

$\mathrm{H}_{\mathrm{a}}: \mathrm{b} \neq 0 \longrightarrow$ ada pengaruh Kredit Macet terhadap Return On Equity (ROE)

b. Menentukan tingkat signifikan $(\alpha)=5 \%$

c. Menetukan $t_{\text {hitung }}$

Berdasarkan hasil uji $\mathrm{t}$ untuk variabel $\mathrm{X}$ (kredit macet) diperoleh $\mathrm{t}_{\text {hitung }}=$ 62,276 .

d. Menetukan $t_{\text {tabel }}$

Dengan menggunakan tingkat signifikan $(\alpha)$ sebesar 5\% untuk uji t dua arah, sehingga $\alpha / 2=0,025 \mathrm{dan} \mathrm{df}=4-2=2$. Dengan demikian $\mathrm{df}=2$ maka $t_{\text {tabel }}$ adalah sebesar 4,303.

e. Menentukan kriteria pengujian

$\mathrm{r}_{\text {hitung }}<\mathrm{r}_{\text {tabel, }}$ maka $\mathrm{H}_{02}$ diterima dan $\mathrm{H}_{\mathrm{a} 2}$ ditolak

$\mathrm{r}_{\text {hitung }}>\mathrm{r}_{\text {tabel, }}$ maka $\mathrm{H}_{02}$ diterima dan $\mathrm{H}_{\mathrm{a} 2}$ ditolak 
$\mathrm{H}_{02}$ diteima jika tingkat signifikan $>0,05$ maka $\mathrm{H}_{\mathrm{a} 2}$ ditolak

$\mathrm{H}_{02}$ ditolak jika tingkat signifikan $<0,05$ maka $\mathrm{H}_{\mathrm{a} 2}$ diterima

f. Keputusan Uji

$\mathrm{H}_{02}$ ditolak karena thitung $(62,276)>\mathrm{t}_{\text {tabel }}(4,303)$, maka $\mathrm{H}_{\mathrm{a} 2}$ diterima.

$\mathrm{H}_{02}$ ditolak karena tingkat signifikan $(0,003)>0.05$, maka $\mathrm{H}_{\mathrm{a} 2}$ diterima.

Melalui hasil perhitungan dapat disimpulkan bahwa secara parsial Kredit Macet berpengaruh secara signifikan terhadap Return On Equity (ROE).

\section{Pembahasan}

\section{(1)Pengaruh Kredit Macet terhadap Return On Assets (ROA)}

Dari analisis data yang telah dilakukan dengan program SPSS versi 23 ditunjukkan dari persamaan regresi linear sederhana yaitu $\mathrm{Y}=1,608+0,278 \mathrm{X}$, dimana Konstanta dengan nilai 1,608 menunjukkan bahwa apabila tidak ada variabel Kredit Macet sama dengan nol, maka Return On Assets (ROA) yang dicapai sebesar 1,608. Koefisien regresi variabel Kredit Macet sebesar 0,278 berarti apabila variabel Kredit Macet sebesar Rp.1. Maka Return On Assets (ROA) akan naik sebesar 0,278.

Kemudian hasil nilai Uji $\mathrm{t}$ diperoleh profitabilitas dengan tingkat signifikan $(\alpha) 5 \%$ sebesar 0,938. Karena nilai profitabilitas ROA sebesar 0,003 < dari 0,05, maka dapat diambil kesimpulan bahwa kredit macet tidak berpengaruh signifikan terhadap ROA. Dengan perhitungan $\mathrm{t}_{\text {tabel }}$ dengan derajat kebebasan $\mathrm{df}=$ $\mathrm{n}-\mathrm{k}=4-2=2$, diperoleh $\mathrm{t}_{\text {tabel }}$ sebesar 4,303, sedangkan menurut perhitungan $\mathrm{t}_{\text {hitung }}$ dengan bantuan SPSS, dihasilkan $t_{\text {hitung }}$ sebesar 19,829. Jadi, 19,829 > 4,303 yang artinya Kredit Macet berpengaruh secara signifikan terhadap Return On Assets (ROA).

\section{(2) Pengaruh Kredit Macet terhadap Return On Equity (ROE)}

Dari analisis data yang telah dilakukan dengan program SPSS versi 23 ditunjukkan dari persamaan regresi linear sederhana yaitu $\mathrm{Y}=6,502+0,792 \mathrm{X}$, diman Konstanta dengan nilai 6,502 menunjukkan bahwa apabila tidak ada variabel Kredit Macet sama dengan nol, maka Return On Equity (ROE) yang dicapai sebesar 6,502. Koefisien regresi variabel Kredit Macet sebesar 0,792 berarti apabila variabel Kredit Macet sebesar Rp.1. Maka Return On Equity 
(ROA) akan naik sebesar 0,792. Berdasarkan hasil analisis data SPSS versi 23 dengan menggunakan taraf signifikan $(\alpha) 5 \%$ atau 0,05 diperoleh nilai $\mathrm{F}$ hitung sebesar 386,112 dengan tingkat signifikansi 0,003 yang lebih kecil dari 0,005, dimana $\mathrm{F}$ hitung $(386,112)$ lebih besar dari nilai $\mathrm{F}$ tabelnya sebesar 18,51 (df1 = k $-1=2-1=1$, df $2=\mathrm{n}-\mathrm{k}=4-2=2$ ). Maka $\mathrm{H}_{02}$ ditolak dan $\mathrm{H}_{\mathrm{a} 2}$ diterima yang berarti Kredit Macet berpengaruh secara signifikan terhadap Return On Equity (ROE). Kemudian hasil nilai uji $\mathrm{t}$ diperoleh profitabilitas dengan tingkat signifikan $(\alpha)$ 5\% sebesar 0,003. Karena nilai profitabilitas ROE sebesar 0,003 < dari 0,05, maka dapat diambil kesimpulan bahwa kredit macet berpengaruh secara signifikan terhadap ROE. Dengan perhitungan $t_{\text {tabel }}$ dengan derajat kebebasan $\mathrm{df}=$ $\mathrm{n}-\mathrm{k}=4-2=2$, diperoleh $\mathrm{t}_{\text {tabel }}$ sebesar 4,303, sedangkan menurut perhitungan $\mathrm{t}_{\text {hitung }}$ dengan bantuan SPSS, dihasilkan $t_{\text {hitung }}$ sebesar 19,650. Jadi, 19,650 > 4,303 yang artinya Kredit Macet berpengaruh secara signifikan terhadap Return On Equity (ROE).

\section{SIMPULAN DAN SARAN}

\section{Simpulan}

Berdasarkan hasil analisis data mengenai Pengaruh Kredit Macet terhadap Profitabilitas bank yang diukur dengan Return On Assets (ROA) dan Return On Equity (ROE) pada PT. Bank Rakyat Indonesia (Persero) Tbk, selama tahun 2016 sampai 2019 dapat diambil kesimpulan bahwa :

1. Kredit Macet berpengaruh terhadap Return On Asset (ROA)

Hal ini ditunjukan oleh besarnya nilai signifkan 0,003 yang lebih kecil dari 0,05 dan $t_{\text {hitung }}$ sebesar 19,829 yang lebih besar dari $t_{\text {tabel }}$ sebesar 4,303, maka $\mathrm{H}_{01}$ ditolak yang berarti kredit macet berpengaruh secara signifikan terhadap Return On Assets (ROA). Dari hasil analisis regresi linier sederhana dengan persamaan $Y=1,608+0,278 X$, maka setiap terjadi kenaikan kredit macet sebesar Rp 1,- maka Return On Assets (ROA) akan mengalami kenaikan sebesar 0,278.

2. Kredit Macet berpengaruh terhadap Return On Equity (ROE)

Hal ini ditunjukan oleh besarnya nilai signifikan sebesar 0,003 yang lebih kecil dari 0,05 dan $t_{\text {hitung }}$ sebesar 19,650 yang lebih besar dari $t_{\text {tabel }}$ 
sebesar 4,303, maka $\mathrm{H}_{01}$ ditolak yang berarti kredit macet berpengaruh secara signifikan terhadap Return On Equity (ROE). Dari hasil analisis regresi sederhana dengan persamaan $\mathrm{Y}=6,502+0,792 \mathrm{X}$, maka setiap terjadi kenaikan kredit macet sebesar Rp 1,- maka Return On Equity (ROE) akan mengalami kenaikan sebesar 0,798.

Berdasarkan hasil penelitian yang menggunakan Program Statistical Product and Service Solution (SPSS) versi 23 bahwa Kredit Macet berpengaruh secara signifikan terhadap Profitabilitas pada PT. Bank Rakyat Indonesia (Persero) Tbk, periode 2016 sampai 2019.

\section{Saran}

Berdasarkan kesimpulan yang diperoleh dalam penlitian ini, maka diajukan saran-saran sebagai pelengkap terhadap hasil penelitian yang dapat diberikan sebagai berikut :

1. Penurunan terhadap kualitas aset, kemampuan perbankan dalam mengahsilkan laba dan likuiditas perbankan hendaknya mendapatkan perhatian serius. Hal ini dapat ditingkatkan melalui analisis terhadap berbagai kondisi yang terjadi dan kebijakan yang tepat terkait dengan kualitas aset, likuiditas dan kemampuan perbankan dalam menghasilkan laba.

2. Penelitian ini hanya terbatas pada satu rasio keuangan saja dalam mengukur kinerja perbankan yaitu Rasio Profitabilitas yang diukur dengan Return On Assets (ROA) dan Return On Equity (ROE). Apabila ingin mendapatkan hail analisis yang lebih komprehensif dalam menilai kinerja perusahaan (bank), penelitian selanjutnya juga bisa menggunakan rasio lainnya seperti Rasio Likuiditas dan Rasio Solvabilias dan diharapkan agar peneliti ini dapat lebih baik lagi

\section{DAFTAR PUSTAKA}

Dendawijaya. 2000. Manajemen Perbankan, Jakarta : Ghalia Indonesia.

Djumhana, Muhammad. 2003. Hukum Perbankan di Indonesia. Bandung : PT. Citra Aditya Bakti. 
Jurnal Ilmiah Akuntansi Rahmaniyah (JIAR)

Vol. 3 No.2, Juni 2020, $66-85$

Permana

Ghozali, Imam. 2011. Aplikasi Analisis Multivariate dan Program SPSS. Semarang : Badan Penerbit Universitas Diponogoro

Kasmir. 2008. Bank dan Lembaga Keuangan lainnya. Jakarta : PT. Rajawali Grafindo Persada.

Kasmir. 2010. Analisis Laporan Keuangan. Jakarta : PT. Rajawali Grafindo Persada.

Kasmir. 2011. Bank dan Lembaga Keuangan lainnya. Jakarta : PT. Rajawali Grafindo Persada.

Nazir, Moh. 2005. Metode Penelitian. Jakarta : Ghalia Indonesia.

Siamat, Dahlan. 2005. Management Lembaga Keuangan Kebijakan Moneter dan Perbankan. Jakarta : Lembaga Penerbit UI.

Soemarso, S.R. 2004. Akuntansi Suatu Pengantar I Edisi 5 Revisi. Jakarta : Salemba Empat.

Sugiyono. 2008. Metodelogi Penelitian Kuantitatif dan $R$ \& D. Bandung : Alfabeta.

Sugiyono. 2010. Metode Penelitian Kuantitatif, Kualitatif dan $R \& D$. Bandung : Alfabeta.

Sugiyono. 2011. Metode Penelitian. Jakarta : Alfabeta.

Sugiyono. 2012. Metode Penelitian Kuantitatif, Kualitatif dan $R \&$ D. Cetakan ke 17. Bandung : Alfabeta.

Sugiyono. 2013. Metode Penelitian Kuantitatif, Kualitatif dan $R \&$ D. Bandung : Alfabeta.

Sugiyono. 2015. Metode Penelitian Kombinasi (Mix Methods). Bandung : Alfabeta.

Suliyanto. 2003. Metode Riset Bisnis. Yogyakarta : Andy.

Taswan. 2010. Manajemen Perbankan Konsep, Teknik, dan Aplikasi. Yogyakarta : UPP STM YKPN.

Umar, Husein. 2004. Metode Riset Ilmu Administrasi. Jakarta : Gramedia Pustaka Utama.

Surat Edaran Bank Indonesia No. 13/I/PBI/2011

Surat Edaran Bank Indonesia No. 6/23/DPNP tanggal 31 Mei 2004 